\title{
Muslim Integration into Western Cultures: Between Origins and Destinations
}

\author{
Pippa Norris \\ Harvard University/University of Sydney
}

\author{
Ronald F. Inglehart \\ University of Michigan/Laboratory for Comparative Social Research
}

\begin{abstract}
To what extent do migrants carry their culture with them, and to what extent do they acquire the culture of their new home? The answer not only has important political implications; it also helps us understand the extent to which basic cultural values are enduring or malleable, and whether cultural values are traits of individuals or are attributes of a given society. The first part of this article considers theories about the impact of growing social diversity in Western nations. We classify two categories of society: Origins (defined as Islamic Countries of Origin for Muslim migrants, including twenty nations with plurality Muslim populations) and Destinations (defined as Western Countries of Destination for Muslim migrants, including 22 OECD member states with Protestant or Roman Catholic majority populations). Using this framework, we demonstrate that, on average, the basic social values of Muslim migrants fall roughly midway between those prevailing in their country of origin and their country of destination. We conclude that Muslim migrants do not move to Western countries with rigidly fixed attitudes; instead, they gradually absorb much of the host culture, as assimilation theories suggest.
\end{abstract}

Keywords: Muslim integration; Islamic societies; Western culture

One of the most striking developments in the modern era of globalization is the rapid flow of people across national borders. The United Nations estimates that, in 2005, 191 million migrants lived outside their country of birth (roughly 3 per cent of the global population) (UNDESA, 2006). This figure has doubled since 1960 and continues to rise; today the estimate is close to 200 million (IOM, 2008). Most move to Western societies; just over two dozen countries of destination, mainly in Europe, North America and Asia, absorb almost three-quarters of all migrants around the world. In 2005, among all world regions, Europe hosted the largest number of international migrants, who represented almost one-tenth of Europe's total population (OECD, 2008).

The rapid settlement of Muslim migrants into European societies, in particular, has raised important challenges for how European policy makers manage cultural diversity, maintain social cohesion and accommodate minorities (Fetzer, 2004; Heckman, 2005). Recent events have intensified concerns about the integration of Muslim populations: (1) sharp ethnic tensions arose in the Netherlands after the murder of film-maker Theo van Gogh by Islamic extremists in November 2004; (2) heated protests broke out in many countries, following the September 2005 publication of the 'Muhammad' cartoons in Denmark: the cartoons were seen as blasphemous in Islamic countries, while demands for their suppression raised concerns about freedom of expression in Western countries; and (3) violent riots occurred a few months later in suburban Paris housing projects involving disaffected FrancoMaghrebi communities. These concerns were heightened by a series of extreme terrorist events, particularly by $9 / 11$ in the United States, and the bombings directed against civilian targets in Madrid (2004), London (2005) and, more recently, Mumbai (2008) (Coolsaet, 2008). The UK was shocked that British-born second-generation Muslim youths of 
Pakistani and Jamaican descent, with good education and job prospects, were the perpetrators of the London bombings. These events raise fears that second-generation Muslims living in isolated urban communities are becoming alienated from democratic societies and may be developing closer sympathies with extremist Islamic movements. For some observers, disaffected Muslims in France, the UK or the Netherlands are seeking to create a society entirely separate from the mainstream (Bawer, 2007).

This backdrop highlights the importance of the broader research question that this study addresses: how far do migrants carry their culture with them, and to what extent do they acquire the culture of their new setting? The answer not only has important political implications; it also helps us understand theoretical debates about whether basic cultural values are enduring or malleable; and whether cultural values are traits of individuals or attributes of a given society.

To explore these issues, the first part of this article considers alternative arguments about the potential consequences of the experience of migration for cultural change. Theories of cultural integration suggest that immigrants gradually absorb the values and norms that predominate in their host society, especially on an intergenerational basis. By contrast, theories of divergence suggest that distinctive social values and norms are enduring and deep-rooted within each nation, shaped by collective histories, common languages and religious traditions, so that migrant populations are unlikely to abandon their cultural roots when they settle in another country. We propose to test these claims by examining whether the basic values of Muslim migrants are closer to those prevailing in their societies of origin or destination. The second part describes the research design and the empirical evidence used in this study, drawing upon the World Values Survey/European Values Study (WVS/ EVS) data set, pooled across five waves from 1981 to 2007. The study compares two types of society: Origins (Islamic Countries of Origin for Muslim migrants, comprising twenty nations with plurality Muslim populations) and Destinations (Western Countries of Destination for Muslim migrants, comparing 22 Organisation for Economic Cooperation and Development (OECD) member states with Protestant or Roman Catholic majority populations) (see Figure 1). ${ }^{1}$

Cultures have multiple dimensions and this study focuses on four important indicators. We analyze attitudes towards gender equality and sexual liberalization, areas in which previous research has demonstrated that a cultural cleavage divides Islamic and Western societies (Norris and Inglehart, 2004; Pettersson, 2008). Muslim practices of forced marriages, polygamy, domestic violence and honor killings, as well as patriarchal beliefs about the traditional roles of women in the family, and the symbolic wearing of the hijab, niqab and burqa, have proved controversial by conflicting with the more egalitarian gender roles, the liberal social values and the secular legal frameworks prevailing in Western countries (Bowen, 2008; Roggeband, 2007). We also compare religious values, where we expect to find strong contrasts between Muslim migrants and the increasingly secular Western publics (Norris and Inglehart, 2004). Lastly, the study compares democratic attitudes, representing important components of civic integration for new citizens in Western countries. Multicultural theories argue that migrants should be engaged in the rights and responsibilities of democratic citizenship in their host societies, even though they should be free to maintain distinct cultural identities, practices and beliefs (Kymlicka and Bashir, 2008). 
Figure 1: The Typological Classification

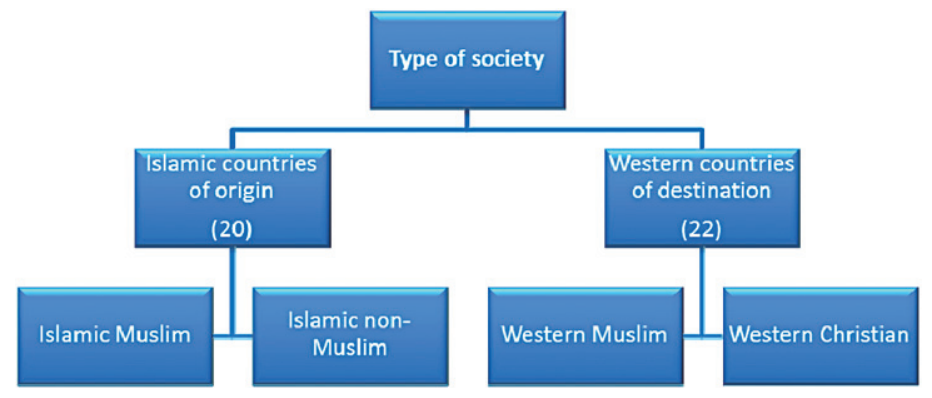

Notes: 'Islamic countries of origin' were classified as those with a plurality Muslim population. 'Western countries of destination' were defined as OECD member states with a plurality Protestant or Roman Catholic population. Within each category, individual Muslims, non-Muslims and Christians were defined by individual religious identities, as monitored in the pooled World Values Survey, 1981-2007.

To analyze the underlying drivers of cultural integration, we examine whether the values under comparison can be explained by: (1) individual-level Muslim religious identities, controlling for many factors that may shape both social values and transnational mobility, including levels of education and socio-economic status, marital status, labor force participation, religiosity, age and gender; or (2) living within Islamic or Western societies, at macro level, controlling for world region. Hierarchical linear models (HLM) are employed, specifically multi-level regression analysis, as the most appropriate technique for examining the strength of both macro-level and individual-level data simultaneously (Bickel, 2007; Gelman and Hill, 2007; Raudenbush and Bryk, 2002). Updating and extending previous research, the results presented in the third part highlight two major findings.

First, as expected, compared with Western nations, Islamic societies prove highly conservative on issues of sexuality and gender equality, including support for egalitarian roles for women in the home, workforce and public sphere. Islamic societies are also far less tolerant towards issues of sexual liberalization, as manifested in their attitudes towards abortion, divorce and homosexuality. Not surprisingly, Islamic societies are also strongly religious in their values, while by comparison most Western countries are almost always more secular. Based on comparing a broader range of Islamic countries, these results update and support findings reported in the previous literature (Inglehart and Norris, 2003b; Norris and Inglehart, 2004).

But this phenomenon does not mean that Muslim immigrants living within Western societies share identical traditional values with their counterparts living in Islamic societies; instead, the analysis demonstrates that the basic values of Muslims living in Western societies fall roughly halfway between the dominant values prevailing within their countries of destination and origin. This suggests that migrant populations living in Rotterdam, Bradford and Berlin are in the process of adapting to Western cultures, while at the same time continuing to reflect the values learned through primary socialization in their countries of origin. The multi-level models used for analysis in this study, controlling for many other 
social characteristics, show that living within an Islamic or Western society has a far stronger imprint on values than individual-level religious identities, or indeed the effects of an individual's education, age, gender and income. Some previous studies argue that Muslim migrants encounter particular difficulties with cultural integration into European societies (Bisin et al., 2008). By contrast, the results of the analysis are largely consistent with previous studies based on other populations, such as the integration of Mexican migrants into the US, suggesting that common underlying processes are at work (Díez Nicolás, 2003; Moreno, 2005).

In interpreting these results, we suspect that, in the short term, one reason why Muslim migrants express values located between their countries of origin and destination may be self-selection: people already sympathetic towards Western cultures, as well as those with the higher skills and status that facilitate mobility, are more likely to relocate to live in affluent post-industrial societies. Nevertheless, in the long term there is probably a reciprocal process at work, especially for the second and third generations of migrant families. Our overall view of these findings is that Muslim migrants do not come to Western countries with rigidly fixed attitudes; instead, they gradually absorb the values prevalent in their host society, as assimilation theories suggest. The fourth part summarizes the key conclusions and reflects upon their broader implications.

\section{Context, Theoretical Framework and Literature Review}

The rate of population migration has accelerated sharply worldwide as part of the phenomenon of globalization - the process of expanding networks of interdependence spanning national boundaries that follows the increasingly swift movement of ideas, money, goods, services, ecology and people across territorial borders (Held et al., 1999; McGrew and Held, 2007). Globalization is understood here as multidimensional, encompassing economic aspects, such as the flow of trade, labor and capital; social aspects, such as interpersonal contacts and mediated information flows; and political dimensions, including the integration of countries into international and regional organizations. In particular, the flow of peoples across national borders has risen due to trade liberalization, economic integration and more open labor markets, as well as international travel and communications, while inter-state wars and internal conflicts have expanded the number of displaced populations and refugees. Western societies are becoming increasingly socially diverse, yet paradoxically the expansion of cosmopolitan communications flowing across state borders has simultaneously weakened the hegemonic control once enjoyed by the major national agencies of cultural transmission, notably domestic television broadcasting channels, within each country. Cosmopolitan communications facilitate multiple information networks linking together the lives of strangers from distant lands, a process that has changed the way we learn about, and interact with, people and places beyond the borders of our country (Kivisto, 2002; Schönpflug, 2009).

These developments have touched all parts of the globe, but Western democracies, with high demand for labor and liberal human rights policies, remain the most attractive destination for migrants and refugees. In 2005, the International Organization for Migration (IOM) estimates that, among all world regions, Europe hosted the highest number of international migrants (70.5 million), followed by North America (45.1 million) and Asia 
(25.3 million). At the dawn of the twenty-first century, about one in four or five residents in countries such as Australia (24 per cent), Switzerland (24 per cent), New Zealand (19 per cent) and Canada (18 per cent) were foreign born, as were one in eight in Germany (13 per cent), the United States (13 per cent) and Sweden (12 per cent) (OECD, 2008). In 2005, just 28 host countries absorbed three-quarters of all migrants worldwide. Social diversity is further reinforced by demographic trends; immigrants from developing societies often have younger age profiles and higher fertility rates than is common in Western countries. Since 2008, the global economic downturn and rising job losses have slowed the demand for low-skilled service labor and migration flows into Western countries, but it is not yet apparent whether this has substantially reversed earlier trends (IOM, 2008).

Due to these developments, European countries that used to be relatively homogeneous in their cultural heritage, historical traditions, ethnic composition, language, lifestyles and religious faith - such as Denmark, France and Sweden - have become far more socially diverse today (Hunter, 1998; 2002; Israeli, 2008). Eurostat reports that in 2007 foreign nationals represent one in four (41 per cent) people living in Luxembourg and one in five living in Switzerland (21 per cent) and Latvia (19 per cent). ${ }^{2}$ Part of this is due to inter-regional mobility within the internal European market, as EU nationals choose to live or work in other member states; the French financial community in Kensington, the British expatriate community in Tuscany or Polish laborers in Spain and Ireland. Most concern about social diversity arises from the challenges of integrating non-EU nationals within member states. Standardized estimates about the exact size of this population derived from official national statistics are not available, but it is commonly suggested that Muslims constitute the largest minority religion within the European Union (BBC News, 2005). Europe has a long history of engagement with Islam and modern developments are rooted in the era of colonial rule; Britain, France and the Netherlands, in particular, experienced large Muslim immigrations after the collapse of their empires. Others came to Europe in the 1950s and 1960s to fill labor shortages. The overall size of the population has also risen because of high birth rates among immigrant families, and refugee flight from impoverished and unstable home countries, such as in the Balkans and Afghanistan. Migration has brought a particularly rapid and profound transformation of many EU societies, nowhere exemplified more dramatically than in poorer city outskirts where Muslim communities have concentrated, such as the population of Turkish guest workers in Berlin, Bremen and Frankfurt; the Moroccan, Turk and Sudanese communities in Rotterdam; FrancoMaghrebis in Marseilles; and Bangladeshis and Pakistanis in the East End of London, Bradford or Leicester (Al-Azmeh and Fokas, 2007; Modood et al., 2006; Nonneman et al., 1998). In response to these developments, Western governments have sought to implement effective policies for managing diversity, while preserving social cohesion, minimizing discrimination and promoting inter-faith tolerance (Gallis, 2005; Sinno, 2009).

What has been the impact of these trends on cultural integration? The theoretical and empirical literature is divided between theories of cultural integration, suggesting that migrants gradually absorb the values and lifestyles of their countries of destination, and theories of multiculturalism, which suggest that enduring traditions, shared identities and deep-rooted values persist for many minority groups for many decades, or even for centuries (Holton, 2000). 


\section{Do Migrants Gradually Absorb the Culture of Their New Destination?}

During the early twentieth century, the Chicago School of sociology sought to understand how successive waves of European immigrants became assimilated or integrated into American society (Kivisto, 2002). The American historical experience from the colonial era until the First World War suggested that migrant populations gradually came to share mainstream values, ways of life and beliefs prevailing in their host society, usually through an intergenerational process (Alba and Nee, 2003). The mainstream agencies of cultural transmission, including schools, the mass media, participation in the labor force and bridging social networks in the local community, facilitated the socialization of second- and third-generation minority groups. During the early twentieth century, assimilation theory was the dominant sociological paradigm for understanding historic waves of immigration by Italian-Americans, Irish-Americans, Polish-Americans and other European émigrés.

As a normative ideal, the concept fell out of favor in America during the 1960s, driven in large part by the civil rights and black power movement, and by the growing diversity of new waves of migrants from around the world, as well as by a reaction discrediting ethnocentric assumptions about the superiority of Anglo-American culture in the United States (Glazer, 2002). In recent years, however, several social scientists have produced revised and updated versions of the assimilation thesis, stripped of its normative connotations. The most comprehensive and analytically rigorous theory, developed by Richard Alba and Victor Nee (2003), identifies a variety of mechanisms that facilitate the integration of minorities into American society, emphasizing the role of human capital, social networks and the institutional arrangements of the state and labor market. Alejandro Portes and Min Zhou (1993) suggest that segmented assimilation typically occurs for second-generation immigrants in the United States, emphasizing that integration into the workforce or community is far from automatic, and it occurs at varying rates for different types of ethnic group. European scholars have been drawing upon these ideas to understand integration occurring among second-generation groups in the EU (Thomson and Crul, 2007). Compared with Europe, however, the United States may prove to be distinctive in its more tolerant cultural attitudes towards migrants, as a society founded historically on the principle of open borders to diverse flows of immigrants.

Most empirical research testing evidence for patterns of cultural integration has compared populations within specific countries but several studies have used cross-national surveys to examine these issues. Support for the thesis is provided by Ronald Inglehart and Christopher Welzel (2005) who analyze plural societies containing large numbers of two long-standing religious communities, comparing Catholics and Protestants, Hindus and Muslims, and Christians and Muslims. Evidence from the WVS/EVS (1999-2001) indicates that religious traditions have historically shaped national cultures - but today their impact is transmitted mainly through nationwide institutions, to the population as a whole. Historically Catholic or Protestant or Islamic societies show very distinctive values, but the differences between Catholics and Protestants and Muslims within given societies proved relatively small. For example, the basic values of German Catholics were closer to those of German Protestants than they were to those of Catholics in other countries: the German Catholics were much more German than Catholic. The same is true in the US, Switzerland, 
the Netherlands and other religiously mixed societies: Catholics tend to be slightly more traditional than their Protestant compatriots in these countries, but they do not fall into the historically Catholic cultural zone or anywhere near it. Rather surprisingly, this also holds true for the differences between Hindus and Muslims in India, and Christians and Muslims in Nigeria: the basic values of Nigerian Muslims are closer to those of their Christian compatriots than they are to those of Indian Muslims. Similar patterns exist for other variables as well: educational, generational, occupational and ethnic differences on the two value dimensions of traditional versus secular-rational authority and survival versus selfexpression values are much smaller within than between societies. Living in a given country has a stronger impact on people's belief systems than their specific type of faith, lending support to the integration theory.

Alejandro Moreno (2005) obtained related findings when he compared Mexicans living in Mexico, Mexicans living in the US and non-Hispanic US citizens. Mexicans in the United States were divided into two subgroups, those who have lived in the US for more than twenty years, and those who have lived there for less than twenty years. He finds that Mexicans living in the US have values that are slightly closer to those of Anglo-Americans than to those of Mexicans living in Mexico; and that Mexicans who have lived in the US for more than twenty years have values that are slightly closer to those of the Americans than are those of Mexicans who have lived there for less than twenty years. Juan Díez Nicolás $(2003 ; 2005)$ made similar comparisons between the social and political values of the Spanish public; the values of immigrants to Spain from Latin America, North Africa, Eastern Europe, sub-Saharan Africa and Asia; and the values of the public in the immigrants' countries of origin. He obtains comparable findings: the values of the immigrants generally fall about halfway between those of the Spanish public and those of their country of origin, but often tend to be somewhat closer to those of their current host country.

These findings lend support to the integration thesis; nevertheless further analysis is required to see whether patterns found for these groups also apply to short-term change among recent Muslim migrant populations. The idea of 'segmented assimilation' developed by Portes and Zhou (1993) holds that minority groups integrate at different rates; in particular, professional and entrepreneurial immigrants usually assimilate their host society's values much faster than those at the bottom of the occupational hierarchy or jobless. It is therefore unclear whether patterns of successful integration, for example those observed for professional and middle-class Jewish, Hispanic or Asian communities in America, also hold for Muslim minorities in Europe, who often come from far poorer developing societies characterized by lower levels of education and literacy. As Alba and Nee argue, groups' rates of assimilation typically differ due to factors such as reservoirs of human capital (educational, vocational and linguistic skills), economic capital (socio-economic status, economic resources) and social capital (social and organizational networks). National groups also differ in how far the values of their countries of origin are congruent with those that predominate in their host society; for example, Polish workers living in Dublin share a common Catholic faith and standards of education, literacy and income that could facilitate integration far more than would be the case with Bangladeshis moving to London. The integration thesis predicts several propositions open to testing with further empirical evidence in this study. In particular, where substantial inter-societal gaps exist between Western and Islamic 
cultures, such as in attitudes towards the family, marriage and the roles of women, assimilation theory predicts that migrants will gradually come to share the predominant values in their country of destination.

\section{Or to What Extent do Migrants Carry Their Original Culture with Them?}

Yet alternative theories of multiculturalism suggest that Muslim migrants, who have acquired deep-rooted and enduring social norms and cultural values through processes of childhood socialization within the family, local community and country, will carry their culture with them when they travel. In this view, persisting ethnic subcultures in multicultural societies, or even deepening divergence between minority and majority communities, seems the most likely scenario. Benedict Anderson (1983) argues that national cultures and collective identities are shaped by common histories, shared languages and deep-rooted religious traditions that persist for centuries. Supporting this claim, empirical analyses by Daron Acemoglu and James Robinson (2006) trace contemporary crossnational differences in economic development and levels of democracy to cultural and institutional differences (or 'nation-specific factors') established as much as 500 years ago. The experience of migration to another country may strengthen the awareness and importance of regional, national or religious identities, rather than weakening them (Gills, 2002; Pearse, 2004; Rusciano, 2006). Historically, traditional ideas of assimilation within American society came under challenge during the 1960s, and the core idea was politically discredited, not least by the persistent structural inequalities that continued to be experienced by African-Americans (Glazer, 2002).

Some empirical evidence also supports observations about enduring cultural differences; Tom Rice and Jan Feldman (1997), analyzing cumulated data from the General Social Survey, find strong correlations between the values of various ethnic groups in the US and the values prevailing in their countries of origin - two or three generations after their families migrated to the US. Ethnographic studies of disaffected Muslim youth, such as Bangladeshis in the UK, report that these groups are turning to revivalist Islam in reaction to political and cultural alienation from the West (Kibria, 2008). Analysis of the UK Fourth National Survey of Ethnic Minorities found that Muslims integrate less fully, and more slowly, than other non-Muslim migrants (Asian, Hindu and Caribbean) (Bisin et al., 2008). In spring 2006, Pew surveys compared public opinion in four European countries (Britain, France, Germany and Spain) alongside Muslim minorities in these countries, reporting that both groups perceived a sense of growing Islamic identity and concern about Islamic extremists (Pew Global Attitudes Project, 2006). The majority of Europeans expressed doubts that Muslims coming into their countries wanted to adopt their national customs and way of life. A subsequent Pew survey in fall 2008 reported that many Europeans also viewed Muslims in an increasingly negative light, especially in France, Germany and Spain (Pew Global Attitudes Project, 2008). As mentioned earlier, the incidence of radical protest involving inter-communal violence, and cases of outright terrorist incidents involving small groups of militant Muslims, lend further plausibility to the divergence argument (Bawer, 2007; Coolsaet, 2008).

There is also systematic evidence that basic cultural values can be remarkably enduring - especially where colonial settlements form the majority population in new settings. 
Support for this claim is demonstrated by the way that colonization from the British Isles or from the Iberian Peninsula seems to have left an impact on the prevailing contemporary values of English-speaking and Latin American societies, an impact that remains clear and distinctive centuries after colonies achieved independence. Thus, analyzing data from the 1990 Values Surveys, Inglehart found evidence that colonial immigrants from given countries tend to bring the values of their society of origin to the new setting, and that these values seem to persist over long periods of time: in global perspective, the basic values of the peoples of Latin American countries were relatively similar to each other, and to the values of the publics of Spain and Portugal (Inglehart, 1997). A similar pattern emerged in the existence of an English-speaking cultural zone, where the publics of Great Britain and Ireland, the US, Canada, Australia and New Zealand showed relatively similar religious, political, economic, social and sexual norms. Analysis of data from subsequent waves of the Values Surveys confirms that these findings are robust over time (Inglehart and Baker, 2000; Inglehart and Welzel, 2005).

If the multiculturalism thesis is correct, then where substantial cultural differences exist between countries of origin and countries of destination, migrants will express values that are closer to those predominating in their country of origin, rather than to those of their destination. Moreover any significant cultural differences among majority and minority populations are not expected to diminish among second- and third-generation migrants; indeed if alienation from the West has occurred, as some observations suggest, then this could even potentially strengthen Muslim identities among younger populations.

\section{Comparative Framework, Evidence and Research Design}

What research design is best suited to analyze the empirical evidence? Much previous survey research seeking to understand these issues has focused on public opinion towards immigration within each host society; for example, Zan Strabac and Ola Listhaug (2008) used the European Social Survey to examine prejudicial attitudes towards ethnic minority populations, while Costas Panagopoulos (2006) examined American attitudes towards Muslims and Arab-Americans in the aftermath of $9 / 11$. Studies have also analyzed public attitudes in Western countries towards the related topics of labor mobility, trade liberalization and economic protectionism (Edwards, 2006; Kaltenthaler et al., 2004; Mayda and Rodrik, 2005). Gallya Lahav (2004) examines European preferences for particular types of immigration policy, at mass and elite levels, showing that many Europeans find immigrants to be threatening. It is important to understand public opinion in Western societies, as perceptions of immigration comprise one of the factors facilitating or restricting processes of integration. But this only reflects one side of the relationship, rather than directly comparing the cultural values of minority and majority populations.

Within-societal comparisons of majority and minority publics have also often been employed. Given the limited sample size of most standard nationwide social surveys, analysis is usually based on specially designed matching surveys that over-sample specific types of minority population. These are exemplified by studies of ethnic minorities, such as Latinos or Muslim American voters, compared with the Anglo-American electorate within the United States (Ayers, 2007). Cross-national studies have also analyzed societal cultures, including a growing body of surveys of public opinion in diverse Muslim-majority 
countries, facilitating comparison with cultures in Western countries (Esposito and Mogahed, 2008; Furia and Lucas, 2008). Our earlier analysis based on the 1999-2001 WVS/EVS documented almost universal support for democratic values in thirteen Islamic societies, with attitudes towards gender equality and sexual liberalization forming the sharpest cleavage dividing Islamic and Western societies (Inglehart and Norris, 2003b). Subsequent studies have further confirmed these patterns in Muslim-majority countries (Dixon, 2008; Meyer et al., 2008). Nevertheless these conclusions need to be revisited, since others have argued that the comparison of Muslim majority societies disguises important subcultures, as attitudes towards democracy and gender equality in the Arab region differ from those of Muslim societies in Asia and elsewhere (Rizzo et al., 2007). Muslim opinion may also vary by the type of state, including among theocracies where Islam is the official religion, such as Iran, absolute autocracies such as Saudi Arabia, and electoral democracies such as Turkey with secular constitutions and a division between mosque and state (Stepan and Robertson, 2003). Just as Evangelicals, Lutherans and Roman Catholics hold distinct theological beliefs and social values, so too predominately Shi'a and Sunni Muslim societies may prove far from homogeneous in their cultures.

Any satisfactory test of these theories, however, needs to examine cultural values at the societal level, as well as among majority and minority populations within countries. This article tests alternative propositions by examining evidence from five pooled waves of the World Values Survey and European Values Study, a global investigation of socio-cultural and political change from 1981 to 2007. This project has conducted representative national surveys of the basic values and beliefs of the publics in more than 90 independent countries, containing over 88 per cent of the world's population and covering all six inhabited continents. The project builds on the European Values Survey, first carried out in 22 countries in 1981. A second wave of surveys was completed in 43 countries in 1990-1. A third wave was carried out in 55 nations in 1995-6, and a fourth wave, in 59 countries, took place in 1999-2001. The fifth wave covering 55 countries was conducted in 2005-7. ${ }^{3}$

Most importantly for our purposes, the survey includes systematic data on public opinion in many diverse Islamic states containing Muslim-plurality populations, providing the broadest comparison available from any existing social survey. Societies in the World Values Survey are classified by their predominant religion, as listed in Table 1. Based on estimates of the religious population contained in the CIA World Factbook, the survey covers twenty Islamic nations, defined as those where the Muslim population is the largest plurality (which may also contain substantial minorities of other faiths). It is important to compare a wide variety of societies to examine the diversity of attitudes and values found among Muslim nations around the globe (Moaddel, 2007). The World Values Survey includes Arab states, both majority Sunni (such as Jordan, Algeria, Morocco and Egypt) and majority Shi'a (such as Iran and Iraq), as well as countries in Asia (Azerbaijan, Kyrgyzstan, Pakistan, Bangladesh, Malaysia), Central Europe (Bosnia Herzegovina, Albania) and in sub-Saharan Africa (Mali, Nigeria, Burkina Faso). The survey also covered states that have adopted Islam as the foundation of political institutions (such as Saudi Arabia and Pakistan), societies where Islam is the official or established state religion (including Egypt, Bangladesh and Malaysia) and secular states where the constitution is neutral towards religion (such as Turkey, Azerbaijan and Indonesia). The World Values Survey contains eight of the ten most populous Muslim 
Table 1: Classification of Countries under Comparison

\begin{tabular}{|c|c|c|c|c|c|c|c|}
\hline & \multicolumn{3}{|c|}{ Countries of origin } & & \multicolumn{3}{|c|}{ Countries of destination } \\
\hline & Country & $\%$ Muslims & Global region & & Country & $\%$ Muslims & Global region \\
\hline 1 & Iraq & 98.9 & Middle East & 1 & France & 1.4 & Western Europe \\
\hline 2 & Algeria & 98.0 & North Africa & 2 & Finland & 1.4 & Scandinavia \\
\hline 3 & Iran & 97.7 & Middle East & 3 & Belgium & 1.2 & Western Europe \\
\hline 4 & Saudi Arabia & 97.0 & Middle East & 4 & Britain & 1.0 & Western Europe \\
\hline 5 & Jordan & 96.9 & Middle East & 5 & Australia & 0.9 & Asia-Pacific \\
\hline 6 & Egypt & 94.3 & North Africa & 6 & Netherlands & 0.7 & Western Europe \\
\hline 7 & Mali & 93.0 & West Africa & 7 & Germany & 0.7 & Western Europe \\
\hline 8 & Indonesia & 92.2 & South East Asia & 8 & Canada & 0.7 & North America \\
\hline 9 & Azerbaijan & 91.0 & Central Asia & 9 & Switzerland & 0.6 & Western Europe \\
\hline 10 & Bangladesh & 88.7 & South Asia & 10 & Luxembourg & 0.6 & Western Europe \\
\hline 11 & Turkey & 81.7 & Central Asia & 11 & N. Zealand & 0.3 & Asia-Pacific \\
\hline 12 & Kyrgyzstan & 74.3 & Central Asia & 12 & Denmark & 0.3 & Scandinavia \\
\hline 13 & Pakistan & 69.6 & South Asia & 13 & Norway & 0.3 & Scandinavia \\
\hline 14 & Albania & 64.3 & Central Europe & 14 & Sweden & 0.2 & Scandinavia \\
\hline 15 & Morocco & 63.6 & North Africa & 15 & USA & 0.2 & North America \\
\hline 16 & Malaysia & 57.4 & South East Asia & 16 & Austria & 0.1 & Western Europe \\
\hline 17 & Burkina Faso & 53.3 & Sub-Saharan Africa & 17 & Spain & 0.1 & Mediterranean Europe \\
\hline 18 & Bosnia Herz. & 48.9 & Central Europe & 18 & Ireland & 0.0 & Western Europe \\
\hline 19 & Tanzania & 40.1 & East Africa & 19 & Greece & 0.0 & Mediterranean Europe \\
\hline \multirow[t]{3}{*}{20} & Nigeria & 28.1 & West Africa & 20 & Iceland & 0.0 & Scandinavia \\
\hline & & & & 21 & Italy & 0.0 & Mediterranean Europe \\
\hline & & & & 22 & Portugal & 0.0 & Mediterranean Europe \\
\hline
\end{tabular}

Source: Pooled World Values Survey, 1981-2007.

nations around the globe, including the top three, Indonesia, Pakistan and Bangladesh. This variation is important as Helen Rizzo et al. (2007) have noted that the comparison of all Islamic societies may overlook important distinctions, since attitudes towards gender equality and sexuality in Arab cultures are expected to be substantially more traditional than those of Asian Islamic cultures.

The WVS/EVS survey covers societies with all levels of economic and human development, including many affluent Western countries, such as the US, Japan and Switzerland, with per capita annual incomes over $\$ 40,000$, together with middle-level Muslim countries including Malaysia, Turkey and Saudi Arabia, as well as poorer Muslim societies, such as Bangladesh, Mali and Burkina Faso, with per capita annual incomes of $\$ 500$ or less. In terms of regimes, Saudi Arabia is an absolute monarchy, which Freedom House classifies as one of the world's most restrictive states in respect of civil liberties and political rights, but the World Values Survey also monitored public opinion in the democratic states of Mali and Indonesia, as well as the secular state of Turkey. ${ }^{4}$

What types of cultural values are selected for comparison? The choice is important, because some types seem to be more deeply embedded in people's personality structure than others, making them relatively resistant to change when an individual moves into a new 
situation. Following Peter Berger and Thomas Luckman (1967), and Thorleif Pettersson, we hypothesize that orientations that are established in one's primary socialization, relatively early in life, such as gender roles, ethnic identities and religious values, are likely to become part of one's core identity, which is relatively resistant to change. Conversely, the formative period for political and economic values seems to occur later in life; such orientations, instilled in one's secondary socialization, are more open to change (Halman and Pettersson, 2003; Pettersson, 1988). Consequently, we expect that migrants would be more likely to change their values concerning politics than those concerning religion and gender roles. Previous research seems to support this expectation (Inglehart and Norris, 2003b; Pettersson, 2007). Although Muslim publics clearly support the goal of democracy, a substantial cultural gap exists between Islamic and Western societies concerning gender equality and sexual liberalization. Moreover, this gap seems to have widened in recent years because, while advanced industrial societies in North America, Western Europe, Japan and Australia have experienced rapid cultural change on issues such as tolerance of homosexuality, divorce and gender equality, the values of pre-industrial societies have been changing relatively slowly.

A series of thirteen items were selected to monitor cultural values towards gender and sexuality, religiosity and democracy, and their dimensions were examined using factor analysis. The results presented in Table 2 show that the items monitoring tolerance of

\section{Table 2: Dimensions of Cultural Value Scales}

\begin{tabular}{|c|c|c|c|c|}
\hline & Religiosity & $\begin{array}{c}\text { Sexual } \\
\text { liberalization }\end{array}$ & $\begin{array}{l}\text { Gender } \\
\text { equality }\end{array}$ & $\begin{array}{c}\text { Democratic } \\
\text { values }\end{array}$ \\
\hline Importance of God scale & 0.719 & -0.434 & & \\
\hline Religious identity & 0.705 & & & \\
\hline Importance of religion & 0.677 & -0.452 & & \\
\hline Frequency of attending religious services & 0.586 & & & \\
\hline Take moments of prayer or meditation? & 0.582 & & & \\
\hline How often think about meaning of life & 0.491 & & & \\
\hline Justifiability abortion & & 0.753 & & \\
\hline Justifiability divorce & & 0.745 & & \\
\hline Justifiability homosexuality & & 0.702 & & \\
\hline Men make better political leaders than women & & & 0.742 & \\
\hline University education more important for a boy & & & 0.719 & \\
\hline Men should have more right to a job than women & & & 0.669 & \\
\hline Having a strong leader rule without elections & & & & 0.772 \\
\hline Having experts, not government, take decisions & & & & 0.686 \\
\hline Having the army rule & & & & 0.611 \\
\hline Approve of having a democratic system & & 0.439 & & 0.419 \\
\hline$\%$ of variance & 16.7 & 16.5 & 13.4 & 10.9 \\
\hline
\end{tabular}

Notes: Individual-level Principal Component Factor Analysis was used to develop the scales with Varimax Rotation and Kaiser Normalization, excluding coefficients below 0.40. See the Technical Appendix for the detailed survey items.

Source: Pooled World Values Survey, 1981-2007. 
homosexuality, abortion and divorce formed one consistent dimension, representing positive orientations towards issues of sexual liberalization and choice. The items concerning gender equality tapped into approval of traditional or egalitarian roles for men and women in the workforce, elected office and university education, forming a consistent scale that we have used in an earlier detailed study (Inglehart and Norris, 2003a). Support for democratic values and principles was monitored using four items: approval of having a democratic political system; agreement or disagreement with questions about having a strong leader who does not have to bother with elections; having experts take decisions instead of government; and having military rule. The separate dimensions were summed and standardized into 100-point scales, for ease of comparison, with the full items listed in the Technical Appendix.

\section{Results and Findings}

The descriptive mean position of the groups on the four 100-point value scales is shown in Figure 2, without applying any controls. The strength and significance of the association was measured by ANOVA. The results of the societal-level comparison demonstrate the existence of a sizeable (25 percentage point) culture gap between Islamic

\section{Figure 2: Cultural Values by Type of Society and Religious Identity}

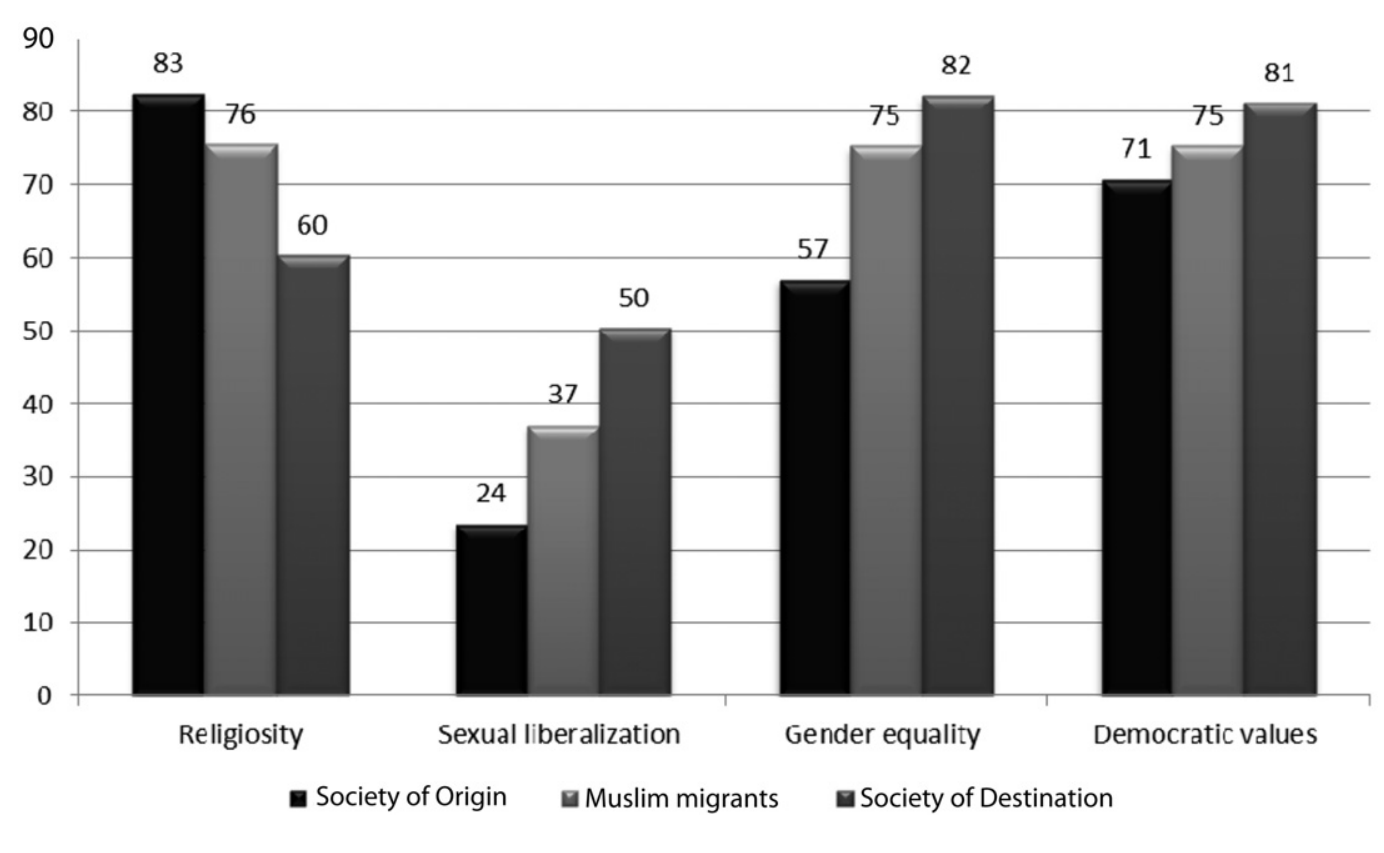

Notes: For the classification, see Figure 1. For the value scales, see the Technical Appendix. Each value scale is standardized to 100 points for ease of comparison. ANOVA tests for differences in means across groups were performed. The strength of association coefficient was measured by eta coefficients, which were statistically significant in every case at the 1 per cent level.

Source: Pooled World Values Survey, 1981-2007. 
countries of origin and Western countries of destination on issues of religiosity, sexual liberalization and gender equality values. On questions such as tolerance of homosexuality, divorce and abortion, for example, Western Christians proved twice as liberal as the more traditional Muslims living in Islamic societies. A far smaller (ten percentage point) gap exists between Islamic and Western countries in support for democratic values, where there was widespread approval. This pattern confirms previous comparisons based on the 1999-2001 WVS/EVS, where the largest gap between Islamic societies and the West was over 'eros not demos' (Inglehart and Norris, 2003b; Norris and Inglehart, 2002). The marked societal contrasts in levels of religiosity have also been documented earlier in detail, with most Western nations proving increasingly secular in religious values and practices, exemplified by the steady erosion of regular attendance at church services in European societies (Norris and Inglehart, 2004).

More importantly for the purposes of this study, the position of Muslim migrants proved to be located approximately halfway between the dominant values prevailing within their Destinations and their Origins. This suggests that Muslims are not exceptionally resistant in levels of integration, as Alberto Bisin et al. (2008) suggest; instead, the centrist position documented in other studies for Mexican and for Latin American migrants also applies to this population (Moreno, 2005). Migrants do not wholly reject their cultural roots, it seems, but neither do they fully adopt the values of their host societies. This pattern was clear and consistent across all the indicators, although the exact location of migrants varied slightly across different cultural scales. It is also striking that although much of the European debate has focused on the attitudes and practices towards the roles of men and women, it appears that on the gender equality scale, Muslim minorities are in fact far closer to Western than to Islamic publics.

To examine the national variations more closely, we constructed scatter plots to compare the mean positions of countries on the gender equality and sexual liberalization scales (Figure 3) and on the democracy and religiosity value scales (Figure 4). In both cases, we find a clear clustering of societies by the predominant type of religion; thus while the Scandinavian countries of Sweden and Norway prove exceptionally egalitarian in their attitudes towards sexuality and gender, the other affluent Western nations such as France, the Netherlands and Switzerland follow close behind. By contrast the Muslim countries, in the bottom left quadrant of Figure 3, prove far more traditional on these issues, notably Arab states such as Saudi Arabia, Jordan and Egypt. Asian and African Islamic societies are slightly more liberal, but they still all remain below the Western societies in this regard. Figure 4, comparing democratic values and religiosity, shows a slightly looser scatter of societies; for example, among the Islamic societies, Tanzania, Azerbaijan and Pakistan show exceptionally high approval of democratic values. Nevertheless, while a less clear-cut division, there is also a pattern apparent with most Muslim societies clustered in the bottom right quadrant, showing less support for democratic ideals and greater religiosity.

So far we have examined the descriptive means at societal levels, but of course before we can attribute these to the type of predominant religion in each society, or to individual Muslim religious identities, we need to control for a number of important variables. After all, Muslim migrants may well prove distinctive from their compatriots for 
Figure 3: Sexual Liberalization and Gender Equality Values by Type of Society

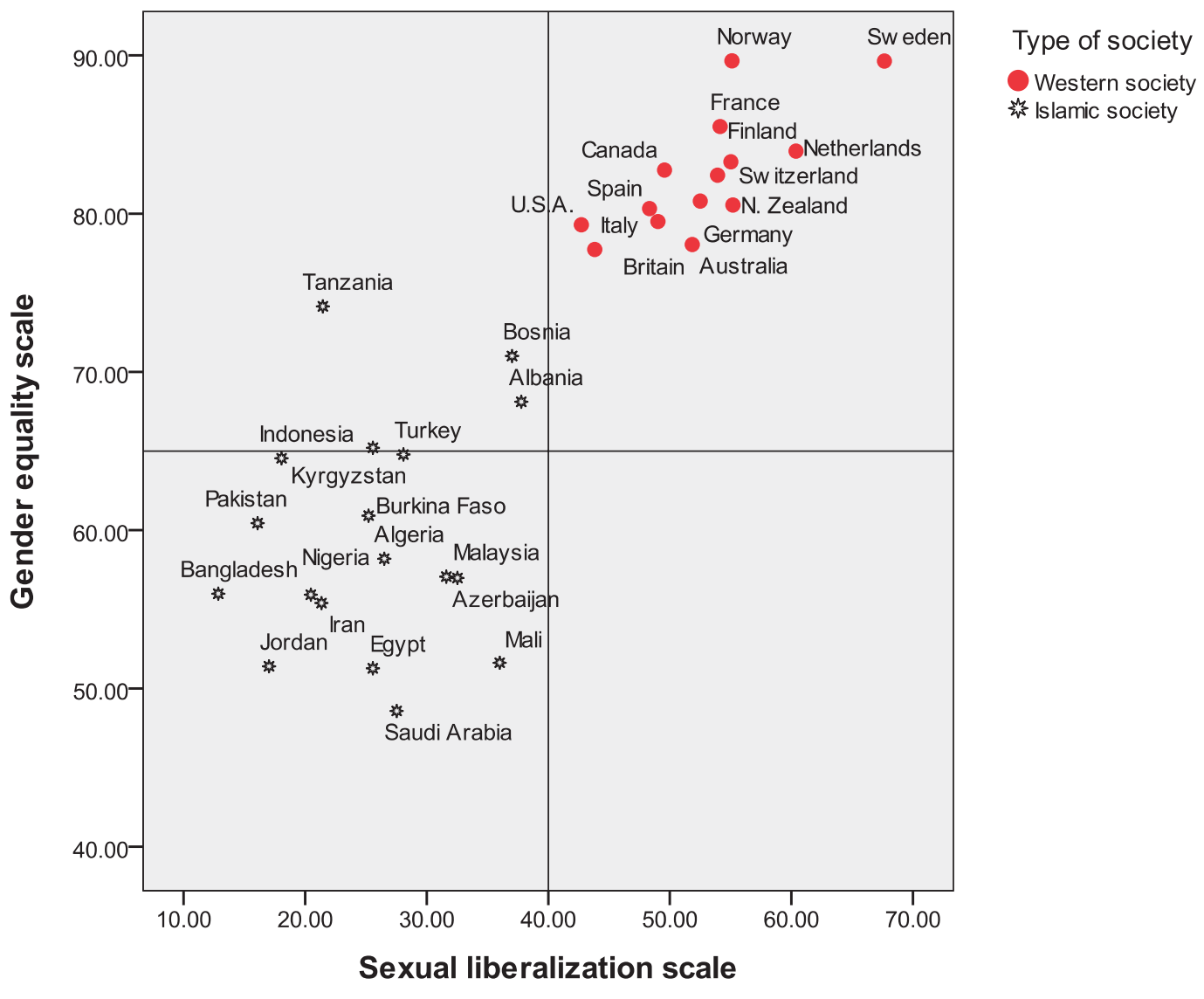

Source: Pooled World Values Survey, 1981-2007.

many reasons; for example, younger groups, and those with greater educational qualifications or higher socio-economic resources, may well find it easier to relocate. The use of hierarchical linear models, in particular multi-level regression analysis, is an appropriate technique for comparing the impact of societal-level and individual-level factors simultaneously. We theorize that Muslim religious identities will have a direct effect on individual values. We also predict that living in Islamic societies will be important for the diffusion of cultural values.

To operationalize these factors, the key models involve measurement at two distinct levels. A representative sample of individual respondents (level 1) is nested within national-level contexts (level 2). The WVS/EVS was conducted among a representative random sample of the adult population within each country. Given the use of multi-level data, HLM are most appropriate for analysis, including multi-level regression analysis. 


\section{Figure 4: Democratic and Religious Values by Type of Society}

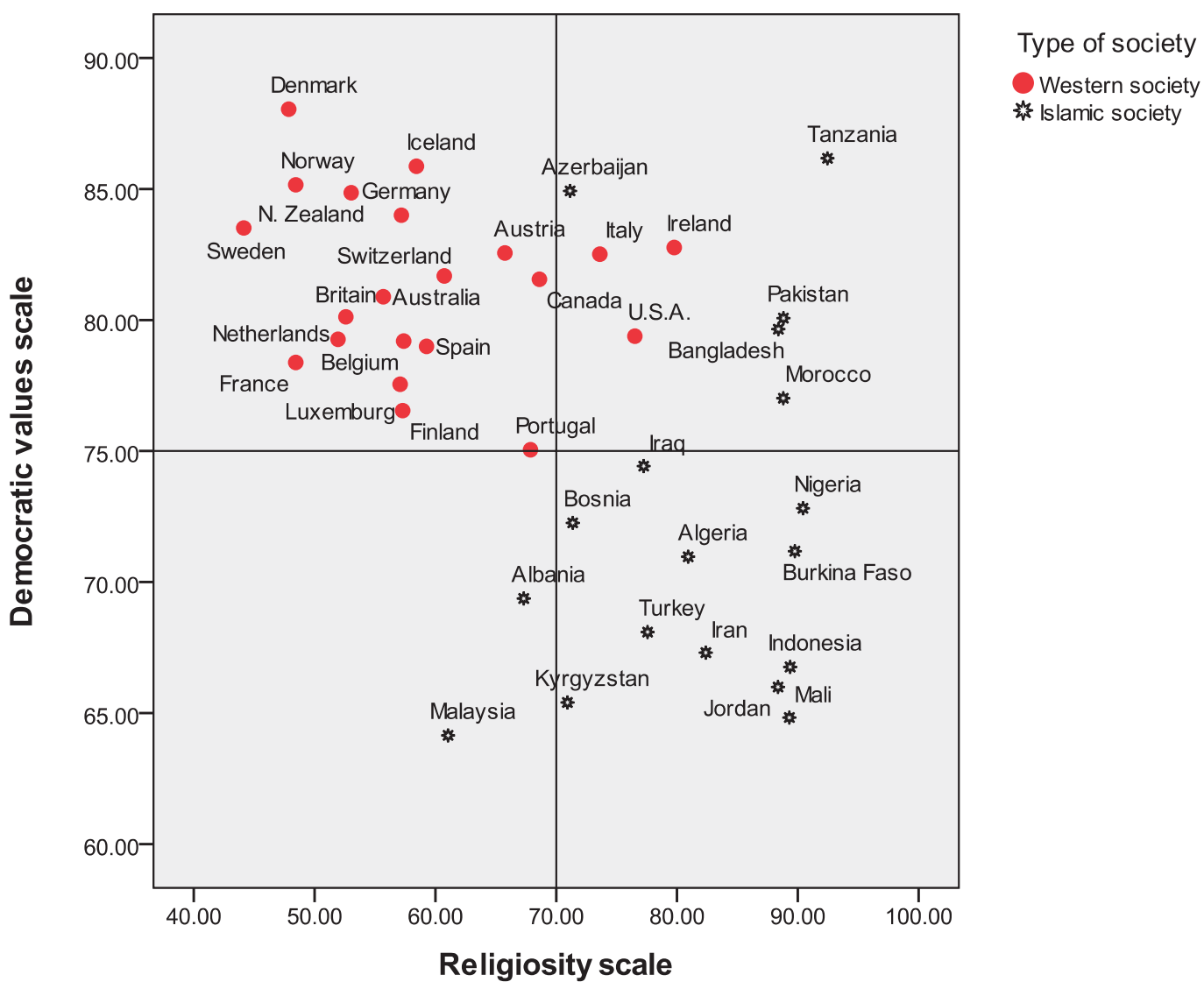

Source: Pooled World Values Survey, 1981-2007.

The models in this study use restricted maximum likelihood techniques (REML) to estimate direct and cross-level effects for hierarchical data. Individual respondents are thus grouped into countries. Each country has a different set of parameters for the random factors, allowing intercepts and slopes to vary by nation (Gelman and Hill, 2007; Raudenbush and Bryk, 2002). The cultural values under comparison are far from uniform in the countries under comparison; hence, for example, there are far more egalitarian attitudes towards gender equality in Northern European and Scandinavian countries than in other European regions (Inglehart and Norris, 2003a). Similarly, the strength of religiosity varies substantially among the countries under comparison, such as stark contrasts between secular Protestant Sweden and Denmark compared with Catholic Italy and Ireland (Norris and Inglehart, 2004). Thus it is important to use techniques that capture this cross-national variance. In hierarchical linear models, as is customary, all independent 
variables were centered, by subtracting the grand mean (which becomes zero). The standardized independent variables all have a standard deviation of 1.0. This process also helps to guard against problems of collinearity in the independent variables in the ordinary least squares (OLS) models. The independent variables were treated as fixed components, reflecting the weighted average for the slope across all groups, while nation was treated as a random component, capturing the country variability in the slope. The strength of the beta coefficients (slopes) can be interpreted intuitively as how much change in the dependent variable is generated by a 1 per cent change in each independent variable. The multi-level regression models used in this study usually generate small differences in the size of the slope coefficient (b) compared with the results of OLS models, but the average standard errors for level 2 variables tend to be slightly larger. The process is thus more rigorous and conservative, avoiding Type I errors (false positives, concluding that a statistically significant difference exists when, in truth, there is no statistical difference). In the REML model, by contrast, Schwarz's Bayesian Information Criterion (BIC) is used, where the model with the lower value is the best fitting.

Level 1 in our core models includes the following individual-level Muslim religious identities, along with several other standard controls, described in the Technical Appendix, including male gender (0/1), household income using a 10 -point scale, age (in years), the education scale, marital status, labor force participation and religiosity (the Importance of God 10-point scale). Level 2 includes national-level variables, including the classification of societies into Islamic or Western Christian (see Table 1), based on the religious proportion of each country's population. In addition, we also control for the location of Islamic countries (classified as in the Middle East or elsewhere in the world), to test whether these societies differ.

Table 3 presents the models predicting cultural values in the Islamic and Western societies under comparison. The models show that both individual religious identities and the type of society influence social values. The type of society, however, consistently provides by far the stronger effect across all value scales; thus, all other things being equal, living in an Islamic society makes a person roughly 10 percentage points more conservative towards sexual morality, about 10 points more religious, roughly 8 percentage points less supportive of gender equality and 3 points less positive towards democratic values. Being a selfidentified individual Muslim, by contrast, has a significant but far weaker effect, although in the same direction. These effects remain significant controlling for many other factors that could plausibly influence social attitudes. The other controls in the models behave mostly as expected; hence education has a liberal effect across all values, while religiosity is associated with more traditional values. Support for tolerance of sexual liberalization values was strengthened by education, household income and labor force participation, while support was weaker among the older generation, those who were married, men and the most devout. Other exploratory models, not reproduced here, found that similar results were generated controlling for other factors, such as use of the mass media and familiarity with a European language, which could facilitate processes of cultural assimilation. A comparison of the standardized coefficients shows that the experience of living in either an Islamic or Western society had a far stronger effect than any other characteristic under comparison. 
Table 3: Full Model Predicting Cultural Values

\begin{tabular}{|c|c|c|c|c|}
\hline & $\begin{array}{l}\text { Gender } \\
\text { equality }\end{array}$ & $\begin{array}{c}\text { Liberal sexual } \\
\text { morality }\end{array}$ & $\begin{array}{c}\text { Democratic } \\
\text { values }\end{array}$ & $\begin{array}{c}\text { Religious } \\
\text { values }\end{array}$ \\
\hline \multicolumn{5}{|l|}{ Predictor variables } \\
\hline Muslim religious identity & $\begin{array}{c}-0.55^{* * *} \\
(0.099)\end{array}$ & $\begin{array}{c}-0.59 * * * \\
(0.123)\end{array}$ & $\begin{array}{c}-0.62^{* * *} \\
(0.086)\end{array}$ & $\begin{array}{l}2.43^{* * *} \\
(0.105)\end{array}$ \\
\hline Islamic society & $\begin{array}{l}-8.22 * * * \\
(0.070)\end{array}$ & $\begin{array}{r}-10.24^{*} \\
(1.06)\end{array}$ & $\begin{array}{c}-3.23^{* * *} \\
(0.940)\end{array}$ & $\begin{array}{l}10.67^{* * *} \\
(1.67)\end{array}$ \\
\hline \multicolumn{5}{|l|}{ Individual-level controls } \\
\hline Age (years) & $\begin{array}{c}-0.96^{* * *} \\
(0.070)\end{array}$ & $\begin{array}{c}-2.01 * * * \\
(0.078)\end{array}$ & $\begin{array}{l}0.97^{* * *} \\
(0.054)\end{array}$ & $\begin{array}{c}3.31^{* * *} \\
(0.068)\end{array}$ \\
\hline Gender $($ male $=1)$ & $\begin{array}{c}-3.83^{* * *} \\
(0.060)\end{array}$ & $\begin{array}{c}-2.08 * * * \\
(0.069)\end{array}$ & $\begin{array}{l}0.52 * * * \\
(0.047)\end{array}$ & $\begin{array}{c}-1.72 * * * \\
(0.060)\end{array}$ \\
\hline Household income 10-pt scale & $\begin{array}{l}1.06 * * * \\
(0.066)\end{array}$ & $\begin{array}{l}1.05^{* * *} \\
(0.074)\end{array}$ & $\begin{array}{l}0.76^{* * *} \\
(0.051)\end{array}$ & $\begin{array}{c}-0.777^{* * *} \\
(0.065)\end{array}$ \\
\hline Education 9-pt scale & $\begin{array}{l}3.06 * * * \\
(0.066)\end{array}$ & $\begin{array}{l}2.98 * * * \\
(0.078)\end{array}$ & $\begin{array}{l}2.63^{* * *} \\
(0.050)\end{array}$ & $\begin{array}{l}\mathbf{0 . 3 1 * * *} \\
(0.067)\end{array}$ \\
\hline Labor force participation & $\begin{array}{l}0.72 * * * \\
(0.063)\end{array}$ & $\begin{array}{l}1.42 * * * \\
(0.073)\end{array}$ & $\begin{array}{c}0.11^{*} \\
(0.050)\end{array}$ & $\begin{array}{c}-0.43^{* * *} \\
(0.064)\end{array}$ \\
\hline Marital status & $\begin{array}{r}-0.52^{* *} \\
(0.062)\end{array}$ & $\begin{array}{c}-1.07^{* * *} \\
(0.071)\end{array}$ & $\begin{array}{l}0.15^{* * * *} \\
(0.049)\end{array}$ & $\begin{array}{l}0.49 * * * \\
(0.062)\end{array}$ \\
\hline 2nd-generation immigrant & $\begin{array}{c}0.17 * * \\
(0.043)\end{array}$ & $\begin{array}{l}0.45 * * * \\
(0.053)\end{array}$ & $\begin{array}{l}0.03 \\
(0.037)\end{array}$ & $\begin{array}{c}0.093^{*} \\
(0.045)\end{array}$ \\
\hline Religiosity & $\begin{array}{c}-1.95 * * * \\
(0.083)\end{array}$ & $\begin{array}{c}-7.67^{* * *} \\
(0.087)\end{array}$ & $\begin{array}{c}-0.48 * * * \\
(0.061)\end{array}$ & \\
\hline \multicolumn{5}{|l|}{ National-level controls } \\
\hline Middle East & $\begin{array}{c}-\mathbf{2 . 5 8 * *} \\
(1.26)\end{array}$ & $\begin{array}{c}-0.090 \\
(1.28)\end{array}$ & $\begin{array}{c}-1.26 \\
(1.07)\end{array}$ & $\begin{array}{c}-0.128 \\
(1.73)\end{array}$ \\
\hline Constant (intercept) & 73.1 & 44.3 & 75.55 & 65.4 \\
\hline Schwarz BIC & 654,224 & 771,651 & 761,323 & 729,290 \\
\hline $\mathrm{N}$ respondents & 78,037 & 87,694 & 94,018 & 85,781 \\
\hline $\mathrm{N}$ nations & 31 & 38 & 38 & 34 \\
\hline
\end{tabular}

Notes: All independent variables were standardized using mean centering (z-scores). Models present the results of the REML multi-level regression models including the beta coefficient (the standard error below in parentheses), and the significance. The 100-point scales are constructed from the items listed in Table 2. ${ }^{*} p>0.05 ;{ }^{* *} p>0.01 ;{ }^{* * *} p>0.001$.

Source: Pooled World Values Survey, 1981-2007.

To see whether generational processes are gradually closing any remaining value gaps, Figure 5 illustrates the attitudes by age category and by type of social group. The graphs show that across each of the value scales, the societal-level gaps largely persist (concerning democracy), or even widen (for sexual liberalization and religiosity), by age group. On religiosity, for example, the younger population in Western societies is increasingly secular 
Figure 5: Values by Age Group and Type of Societal-Religious Identity
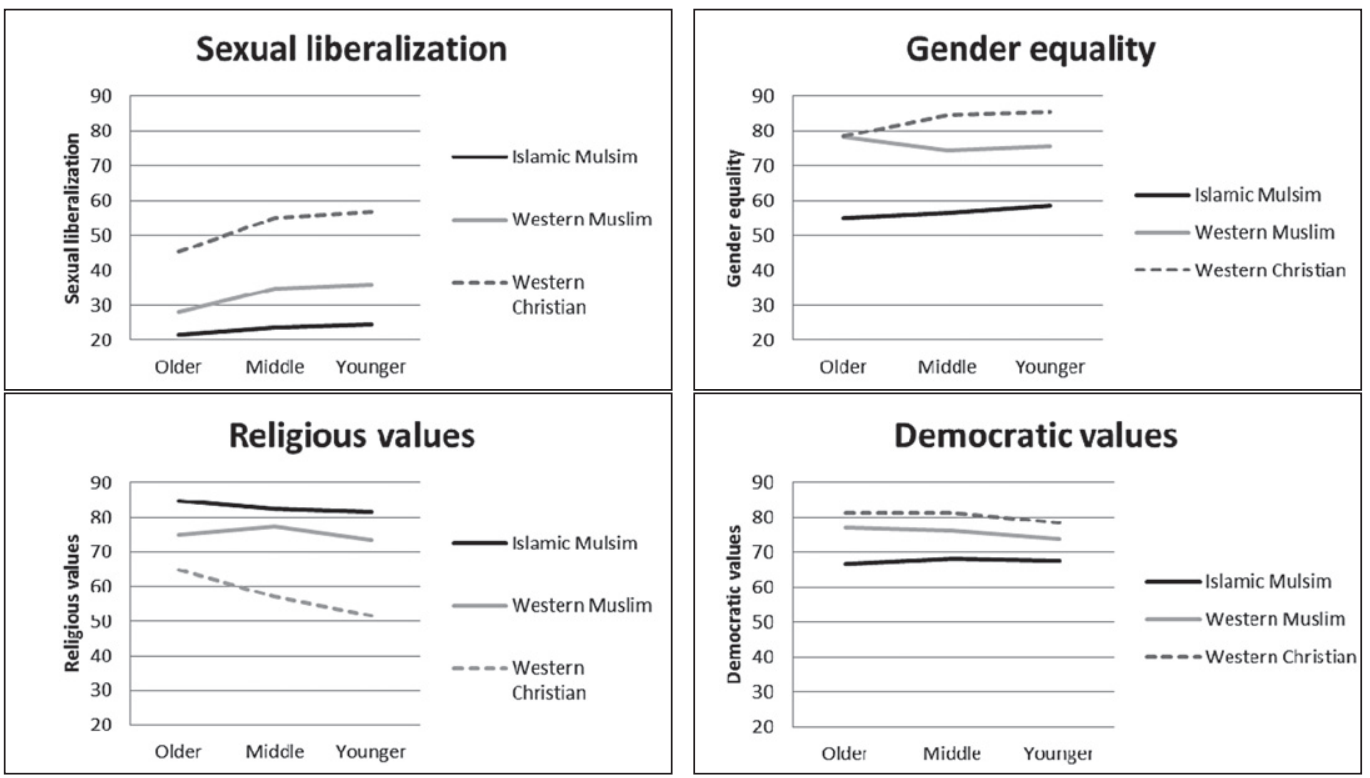

Source: Pooled World Values Survey, 1981-2007.

compared with older generations. By contrast, Islamic Muslims, and Western Muslims, show a far slower process of age-related change towards religious values. Similar observations can be made concerning attitudes towards sexual liberalization; here younger Western Muslims are indeed becoming more tolerant than middle-aged and older generations, but the change among Western publics is far greater. As a result, although Western Muslims are consistently located between Islamic and Western societies, there is no evidence that generational change, by itself, will transform the situation so that the cultural differences between Muslim migrants and Western publics will disappear: younger Westerners are adopting modern values even more swiftly than their Muslim peers.

\section{Conclusions and Implications}

There has been widespread public debate about how far Western societies can manage the growing social diversity produced by the rising influx of migrants flowing across national borders and, in particular, the rapidly expanding Muslim population living within Europe. During earlier historical eras, the United States assimilated successive waves of people, whether Irish, Italian or Polish Catholics, Central European Jews or Scandinavian Lutherans, as well as later populations drawn from around the globe, whetherVietnamese refugees, Korean shopkeepers and Indian software engineers or Liberian, Colombian or Mexican laborers and service workers. Can historically more homogeneous European cultures, such as Sweden, France and Germany, also manage to accommodate greater social diversity 
successfully? Or will immigration deepen cultural tensions, social instability and intracommunal conflict in Europe, especially when tested under conditions of deep-rooted economic recession and joblessness?

As we demonstrate, cultural cleavages do exist. They are not monolithic. The largest differences between Muslim and Western societies are found in religiosity, gender roles and sexual norms. This does not mean that migrants are constructing a subculture that is entirely separate from the mainstream national cultures of Western societies; instead, Muslim migrants living in Western societies are located roughly in the center of the cultural spectrum, located between the publics living in Islamic and Western societies. It is entirely possible - indeed, we think it rather likely - that some degree of self-selection may be involved: those who choose to immigrate to the US or to Spain may already have values that are relatively compatible with those of their future host country. But even if this is true, these findings contradict the idea that immigrants simply import an unmodified version of the values of their own country into their new host country. In the long term, the basic cultural values of migrants appear to change in conformity with the predominant culture of each society.

Nevertheless, substantial national differences are apparent, and the gap between Muslim and Western societies is particularly large. They do not concern fundamental disagreement about whether democracy is a desirable form of government. But they do involve tolerance of sexual liberalization and women's equality - and tolerance is a particularly crucial aspect of a democratic political culture. Do such cultural differences necessarily lead to tensions or even clashes? No. Under high levels of existential insecurity, xenophobia and intolerance are particularly intense and likely to lead to violence. Conversely, conditions of security are conducive to relative tolerance of diversity; indeed, at high levels of existential security, cultural pluralism is regarded as enriching the diversity of lifestyles, the range of choices that are open to people. Cultural differences are a potential fault-line that demagogues can exploit to inflame hatred between groups. But there is nothing inevitable about cultural conflict. Depending on conditions, diversity can be seen either as threatening or as a positive contribution towards the innovation and creativity that make society and economies adapt successfully to new challenges in a globalized world. 


\section{Technical Appendix: Concepts and Measures}

Variable

Per capita GDP

Type of religion

Type of predominant religion worldwide

Gender equality scale

Sexual liberalization values scale

Democratic values scale

Religious values scale

Occupational class

Paid work status

Education

Age

Language

Religiosity

Household income

Education scale
Definitions, coding and sources

Measured in constant international \$ in Purchasing Power Parity. Various years. Source: The World Bank; World Development Indicators.

V184: 'Do you belong to a religious denomination? [IF YES] Which one? Coded: No, not a member; Roman Catholic; Protestant; Orthodox (Russian/Greek/etc.); Jewish; Muslim; Hindu; Buddhist; Other. Source: World Values Survey.

The classification of the major religion (adhered to by the plurality groups in the population) in all 193 states around the world is based on the CIA, The World Factbook, 2009 (Washington, DC: Central Intelligence Agency). Source: http://www.cia.gov/cia/publications/factbook

The combined 100-pt gender equality scale is based on the following 3 items: MENPOL 0118: 'On the whole, men make better political leaders than women do'. (Agree coded low); MENJOBS 078: 'When jobs are scarce, men should have more right to a job than women'. (Agree coded low); BOYEDUC 0.119: 'A university education is more important for a boy than a girl'. (Agree coded low). Source: World Values Survey.

'Please tell me for each of the following statements whether you think it can always be justified (10), never justified (1), or somewhere in-between, using this card ... Abortion, Homosexuality, Divorce'. Source: World Values Survey.

V148-151. 'I'm going to describe various types of political system and ask what you think about each as a way of governing this country. For each one, would you say it is a very good, fairly good, fairly bad or very bad way of governing this country? Having a strong leader who does not have to bother with parliament and elections/Having experts, not government, make decisions/Having the army rule/Having a democratic political system?' Source: World Values Survey.

This is a composite 100-point scale constructed by summing the following items: Importance of God, Religious identity, Importance of religion, Frequency of attending religious services, Take moments of prayer or meditation, How often think about meaning of life?

Coded for the respondent's occupation. 'In which profession/occupation do you, or did you, work?' The scale is coded into 4 categories: Professional/manager (1); Other non-manual (2); Skilled non-manual (3); Unskilled manual worker (4). Source: World Values Survey.

V220. 'Are you employed now or not?' Coded full-time, part-time or self-employed (1), other (0). Source: World Values Survey.

V217. 'What is the highest educational level that you have ever attained?' Coded on a 9-point scale from no formal education (1) to university level with degree (9). Source: World Values Survey.

Age coded in continuous years derived from date of birth. Source: World Values Survey.

Age groups: younger (18-29), middle (30-49) and older (50+).

V222. 'What language do you normally speak at home?' Code English $=1$, else $=0$. Source: World Values Survey.

V192 'How important is God in your life?' 10-point scale.

V253 'On this card is a scale of incomes on which 1 indicates the "lowest income decile" and 10 the "highest income decile" in your country. We would like to know in what group your household is. Please, specify the appropriate number, counting all wages, salaries, pensions and other incomes that come in.' (Code one number). Source: World Values Survey.

V238. 'What is the highest educational level that you have attained?' [NOTE: if respondent indicates to be a student, code highest level $s /$ he expects to complete]:

(1) No formal education; (2) Incomplete primary school; (3) Complete primary school; (4) Incomplete secondary school: technical/vocational type; (5) Complete secondary school: technical/vocational type; (6) Incomplete secondary: university-preparatory type; (7) Complete secondary: university-preparatory type; (8) Some university-level education, without degree; (9)University-level education, with degree. Source: World Values Survey.

Note: Full details of the World Values Survey codebooks and questionnaires can be found at http://www.worldvaluessurvey.com 


\section{(Accepted: 27 December 2011)}

\section{About the Authors}

Pippa Norris is the McGuire Lecturer in Comparative Politics at the John F. Kennedy School of Government, Harvard University and also ARC Fellow and Professor of Government at the University of Sydney. Pippa Norris, John F. Kennedy School of Government, 110 Littauer Building, Harvard University, 79 JKF Street, Cambridge MA 02138, USA; email: Pippa_Norris@Harvard.edu

Ronald F. Inglehart is Professor of Political Science in the Institute for Social Research, the University of Michigan, and also Director, Laboratory for Comparative Social Research, Higher School of Economics Moscow and St Petersburg. Ronald F. Inglehart, Department of Political Science, 5700 Haven Hall, University of Michigan, 505 South State Street, Ann Arbor MI 48109-1045, USA; email: ringlehart@gmail.com

\section{Notes}

1 It should be noted that throughout the article the term 'Islamic' is used to refer to Muslim majority societies, and it is not used to describe the official religion or policies of the state, or the relation between religious and political authorities. 'Muslim' is used throughout to refer to individuals who identify with the Muslim faith.

2 Eurostat, European Statistics. ec.europa.edu/eurostat. For more detailed figures, see The European Migration Network, http:// www.european-migration-network.org/

3 Full methodological details about the World Values Survey, including the questionnaires, sampling procedures, fieldwork procedures, principle investigators and organization can be found at: http://wvs.isr.umich.edu/wvs-samp.html

4 These regimes are classified according to the 2008 Freedom House assessments of political rights and civil liberties. Freedom House, Freedom in the World, 2008, http://www.freedomhouse.org

\section{References}

Acemoglu, D. and Robinson, J. A. (2006) Economic Origins of Dictatorship and Democracy. Cambridge: Cambridge University Press.

Al-Azmeh, A. and Fokas, E. (2007) Islam in Europe: Diversity, Identity and Influence. New York: Cambridge University Press. Alba, R. and Nee, V. (2003) Remaking the American Mainstream: Assimilation and Contemporary Immigration. Cambridge MA: Harvard University Press.

Anderson, B. (1983) Imagined Communities: Reflections on the Origin and Spread of Nationalism. London: Verso.

Ayers, J. W. (2007) 'Changing Sides: 9/11 and the American Muslim Voter', Review of Religious Research, 49 (2), 187-98.

Bawer, B. (2007) While Europe Slept: How Radical Islam is Destroying the West from Within. New York: Anchor.

BBC News (2005) Muslims in Europe, Country Guide. Available from: http,//news.bbc.co.uk/2/hi/europe/4385768.stm [Accessed 6 July 2011].

Berger, P. and Luckmann, T. (1967) The Social Construction of Reality: A Treatise in The Sociology of Knowledge. New York: Anchor. Bickel, R. (2007) Multilevel Analysis for Applied Research: It's Just Regression! New York: Guilford Press.

Bisin, A., Patacchini, E., Verdier, T. and Zenou, Y. (2008) 'Are Muslim Immigrants Different in Terms of Cultural Integration?', Journal of the European Economic Association, 6 (2-3), 445-56.

Bowen, J. R. (2008) Why the French Don't Like Headscarves: Islam, the State, and Public Space. Princeton NJ: Princeton University Press.

Coolsaet, R. (2008) Jihadi Terrorism and the Radicalisation Challenge in Europe. Aldershot: Ashgate.

Díez Nicolás, J. (2003) 'Two Contradictory Hypotheses on Globalization: Societal Convergence, Civilization Differentiation and Clash', in R. Inglehart (ed.), Human Values and Social Change. Leiden: Brill, pp. 235-63.

Díez Nicolás, J. (2005) Las dos caras de la inmigración. Madrid: Ministerio de Trabajo y Asuntos Sociales.

Dixon, J. C. (2008) 'A Clash of Civilizations? Examining Liberal-Democratic Values in Turkey and the European Union', British Journal of Sociology, 59 (4), 681-708.

Edwards, M. S. (2006) 'Public Opinion Regarding Economic and Cultural Globalization: Evidence from a Cross-National Survey', Review of International Political Economy, 13 (4), 587-608.

Esposito, J. L. and Mogahed, D. (2008) Who Speaks for Islam? What a Billion Muslims Really Think. Princeton NJ: Gallup Press. Fetzer, J. S. (2004) Muslims and the State in Britain, France, and Germany. New York: Cambridge University Press.

Furia, P. A. and Lucas, R. E. (2008) 'Arab Muslim Attitudes toward the West: Cultural, Social, and Political Explanations', International Interactions, 34 (2), 186-207.

Gallis, P. (2005) Muslims in Europe: Integration Policies in Selected Countries, Congressional Research Service. Washington DC: Library of Congress.

Gelman, A. and Hill, J. (2007) Data Analysis using Regression and Multilevel/Hierarchical Models. New York: Cambridge University Press.

Gills, B. K. (2002) Globalization and the Politics of Resistance. London: Palgrave Macmillan.

Glazer, N. (2002) 'Is Assimilation Dead?', in P. Kivisto (ed.), Multiculturalism in a Global Society. Oxford: Blackwell, pp. 78-90. 
Halman, L. and Pettersson, T. (2003) 'Religion und Politik in Zeitgenössischen Geschellshaft: Differentzieurung oder Entdifferentzierung', in M. Minkenberg and U. Willems (eds), Politik und Religion: Politische Viertaljahresschrift. Berlin: VS Verlag für Sozialwissenschaften, pp. 20-31.

Heckman, F. (2005) 'National Modes of Immigrant Integration.', in W. Bosswick and C. Husbanded (eds), Comparative European Research in Migration, Diversity and Identities. Bilbao: University of Duesto, pp. 99-112.

Held, D., McGrew, A., Goldblatt, D. and Perraton, J. (1999) Global Transformations: Politics, Economics, and Culture. Stanford CA: Stanford University Press.

Holton, R. (2000) 'Globalization's Cultural Consequences', Annals of the American Academy of Political and Social Sciences, 570 , $140-52$.

Hunter, S. (1998) The Future of Islam: Clash of Civilizations or Peaceful Coexistence? London: Praeger.

Hunter, S. (2002) Islam, Europe's Second Religion: The New Social, Cultural and Political Landscape. London: Praeger.

Inglehart, R. (1997) Modernization and Post-modernization: Cultural, Economic and Political Change in 43 Societies. Princeton NJ: Princeton University Press.

Inglehart, R. and Baker, W. (2000) 'Modernization, Cultural Change and the Persistence of Traditional Values', American Sociological Review, 65 (1), 19-51.

Inglehart, R. and Norris, P. (2003a) Rising Tide. New York: Cambridge University Press.

Inglehart, R. and Norris, P. (2003b) 'Islam and the West: A "Clash of Civilizations", , Foreign Policy, 135 (March/April), 62-70.

Inglehart, R. and Welzel, C. (2005) Modernization, Cultural Change and Democracy: The Human Development Sequence. New York: Cambridge University Press.

IOM (2008) World Migration 2008: Managing Labour Mobility in the Evolving Global Economy. International Organization for Migration. Available from: http://www.iom.int [Accessed 6 July 2011].

Israeli, R. (2008) The Islamic Challenge in Europe. New Brunswick NJ: Transaction Publishers.

Kaltenthaler, K. C., Gelleny, R. D. and Ceccoli, S. J. (2004) 'Explaining Citizen Support for Trade Liberalization', International Studies Quarterly, 48 (4), 829-51.

Kibria, N. (2008) 'The "New Islam” and Bangladeshi Youth in Britain and the US', Ethnic and Racial Studies, 31 (2), $243-66$.

Kivisto, P. (2002) Multiculturalism in a Global Society. Oxford: Blackwell.

Kymlicka, W. and Bashir, B. (2008) The Politics of Reconciliation in Multicultural Societies. Oxford: Oxford University Press.

Lahav, G. (2004) Immigration and Politics in the New Europe. Cambridge: Cambridge University Press.

McGrew, A. and Held, D. E. (eds) (2007) Globalization Theory: Approaches and Controversies. Cambridge: Polity.

Mayda, A. M. and Rodrik, D. (2005) 'Why are some People (and Countries) more Protectionist than Others?', European Economic Review, 49 (6), 1393-430.

Meyer, K., Tope, D. and Price, A. M. (2008) 'Religion and Support for Democracy: A Cross-National Examination', Sociological Spectrum, 28 (5), 625-53.

Moaddel, M. (ed.) (2007) Values and Perceptions of the Islamic and Middle Eastern Publics. New York: Palgrave McMillan.

Modood, T. A., Triandafyllidou, A. and Zapata-Barrero, R. (eds) (2006) Multiculturalism, Muslims and Citizenship:A European Approach. London: Routledge.

Moreno, A. (2005) Nuestros Valores: México y los Mexicanos en Estados Unidos al inicio del siglo 21. Mexico City: Banamex Centro de Estudios Económicos y Sociopolíticos.

Nonneman, G., Niblock, T. and Szajkowski, B. (1998) Muslim Communities in the New Europe. Ithaca NY: Ithaca Press.

Norris, P. and Inglehart, R. (2002) 'Islamic Culture and Democracy: Testing the Clash of Civilizations Thesis', Comparative Sociology, 1 (3/4), 235-64.

Norris, P. and Inglehart, R. (2004) Sacred and Secular. New York: Cambridge University Press.

OECD (2008) International Migration Outlook. Paris: OECD. Available from: http://www.oecd.org/els/migration/imo [Accessed 6 July 2011].

Panagopoulos, C. (2006) 'The Polls-Trends: Arab and Muslim Americans and Islam in the Aftermath of 9/11', Public Opinion Quarterly, 70 (4), 608-24.

Pearse, M. (2004) Why the Rest Hates the West: Understanding the Roots of Global Rage. New York: InterVarsity Press.

Pettersson, T. (1988) Bakom Dubbla lås: En Studie av små och Långsamma Värdeingsförändringar. Stockholm: Allmänna förlaget.

Pettersson, T. (2007) 'Muslim Immigrants in Western Europe: Persisting Value Differences or Value Adaptation?', in M. Moaddel (ed.), Values and Perceptions of the Islamic and Middle Eastern Publics. New York: Palgrave McMillan, pp. 54-60.

Pettersson, T. (2008) 'Basic Values and Civic Education: A Comparative Analysis of Adolescent Orientations towards Gender Equality and Good Citizenship', in B. Hettne (ed.), Human Values and Global Governance: Studies in Development, Security and Culture. New York: Palgrave McMillan, pp. 103-20.

Pew Global Attitudes Project (2006) Muslims in Europe: Economic Worries Top Concerns about Religious and Cultural Identity. Available from: http//pewglobal.org/reports/display.php?ReportID=254 [Accessed 6 July 2011].

Pew Global Attitudes Project (2008) Unfavorable Views of Jews and Muslims on the Increase in Europe. Available from: http://pewglobal.org/reports/display.php?ReportID=262 [Accessed 6 July 2011].

Portes, A. and Zhou, M. (1993) 'The New Second Generation: Segmented Assimilation and Its Variants', American Academy of Political and Social Science, 530, 74-96.

Raudenbush, S. W. and Bryk, A. S. (2002) Hierarchical Linear Models, second edition. Thousand Oaks CA: Sage.

Rice, T. W. and Feldman, J. L. (1997) 'Civic Culture and Democracy from Europe to America', Journal of Politics, 59 (4), $1143-72$. 
Rizzo, H., Abdel-Latif, A. H. and Meyer, K. (2007) 'The Relationship between Gender Equality and Democracy: A Comparison of Arab Versus Non-Arab Muslim Societies', Sociology: The Journal of the British Sociological Association, 41 (6), 1151-70.

Roggeband, C. (2007) 'Dutch Women are Liberated, Migrant Women are a Problem: The Evolution of Policy Frames on Gender and Migration in the Netherlands (1995-2005)', Social Policy \& Administration, 41 (3), 271-88.

Rusciano, F. L. (2006) Global Rage after the Cold War. New York: Palgrave Macmillan.

Schönpflug, R. (2009) Cultural Transmission: Psychological, Developmental, Social, and Methodological Aspects. Cambridge: Cambridge University Press.

Sinno, A. H. (2009) Muslims in Western Politics. Bloomington IN: Indiana University Press.

Stepan, A. and Robertson, G. B. (2003) 'An "Arab" more than "Muslim” Electoral Gap', Journal of Democracy, 14 (3), 30-44.

Strabac, Z. and Listhaug, A. (2008) 'Anti-Muslim Prejudice in Europe: A Multilevel Analysis of Survey Data from 30 Countries', Social Science Research, 37 (1), 268-86.

Thomson, M. and Crul, M. (2007) 'The Second Generation in Europe and the United States: How is the Transatlantic Debate Relevant for Further Research on the European Second Generation', Journal of Ethnic and Migration Studies, 33 (7), 1025-41.

UNDESA (2006) Trends in the Total Migrant Stock (2005). New York: United Nations Economic and Social Affairs, Population Division. Available from: http//www0.un.org/esa/population/publications/migration/migration(2005)htm [Accessed 6 July 2011]. 